\title{
SENGAJA DAN TIDAK SENGAJA DALAM HUKUM PIDANA INDONESIA
}

\author{
Marsudi Utoyo, Kinaria Afriani, Rusmini, Husnaini \\ Dosen, Sekolah Tinggi Ilmu Hukum Sumpah Pemuda \\ mutoyo68@gmail.com, riakirey.82@gmail.com
}

\begin{abstract}
Abstrak
Tindak Pidana adalah suatu perbuatan yang pelakunya dapat dikenakan hukuman pidana. Pelaku ini dapat dikatakan merupakan "subyek" tindak pidana. Bahwa pertanggungjawaban pidana diartikan sebagai diteruskannya celaan yang objektif yang ada pada perbuatan pidana dan secara subjektif memenuhi syarat untuk dapat dipidana karena perbuatannya itu. Yang dimaksud dengan kesalahan adalah Kesalahan adalah dasar untuk pertanggungjawaban. Kesalahan merupakan keadaan jiwa dari si pembuat dan hubungan batin antara si pembuat dan perbuatannya. Mengenai keadaan jiwa dari seseorang yang melakukan perbuatan, lazim disebut sebagai kemampuan bertanggung jawab, sedangkan hubungan batin antara si pembuat dan perbuatannya itu merupakan kesengajaan, kealpaan, serta alasan pemaaf.Dengan demikian, untuk menentukan adanya kesalahan, dalam pidana subjek hukum harus memenuhi beberapa unsur, antara lain: Adanya kemampuan bertanggung jawab pada si pelaku, Perbuatannya tersebut berupa kesengajaan (dolus) atau kealpaan (culpa); Tidak adanya alasan penghapus kesalahan atau tidak adanya alasan pemaaf. Pengertian "Sengaja dan Tidak Sengaja" dalam hukum pidana Indonesia adalah Kesengajaan itu adalah "menghendaki" dan "mengetahui" (willens en wetens). Maksudnya adalah seseorang yang melakukan suatu perbuatan dengan sengaja itu, haruslah menghendaki (willens) apa yang ia perbuat dan harus mengetahui pula (wetens) apa yang ia perbuat tersebut beserta akibatnya.
\end{abstract}

\section{Kata Kunci : Kesalahan, kesengajaan, kealpaan}

\section{Abstract}

Criminal action is an act for which the perpetrator is subject to criminal penalties. This perpetrator can be said to be the "subject" of a criminal act. Whereas criminal liability is defined as the continuation of an objective reproach that is in the criminal act and subjectively meets the requirements to be convicted of that act. What is meant by error is error is the basis for accountability. Mistakes are the mental state of the maker and the inner connection between the maker and the deeds. Regarding the mental state of a person who does an action, it is commonly referred to as the ability to be responsible, while the mental relationship between the maker and the action is deliberate, negligent, and excuses for forgiveness. Thus, in order to determine an error, a legal subject must fulfill several elements, among others: The ability to be responsible to the perpetrator, the act is in the form of intent (dolus) or negligence (culpa); There is no excuse for erasing mistakes or the absence of excuses for forgiveness. The definition of "Intentional and Unintentional" in Indonesian criminal law is intentional, it means "willing" and "knowing" (willens en wetens). The point is that someone who commits an act deliberately, must will (willens) what he does and must also know (wetens) what he is doing and its consequences.

Keywords: mistake, deliberate, negligence 


\section{A. PENDAhuluan}

Beberapa waktu belakangan publik ramai memperbincangkan Jaksa Penuntut Umum dalam Kasus Novel Baswedan yang menuntut para Terdakwa dalam kasus tersebut dengan tuntutan 1 tahun penjara dengan alasan para Terdakwa "tidak sengaja" melukai mata Novel. Penuntut Umum menyebutkan bahwa kedua Terdakwa "tidak sengaja" menyiram air keras ke wajah Novel. Menurut jaksa, keduanya hanya ingin menyiramkan air keras tersebut ke tubuh Novel.Jaksa juga menyatakan bahwa dalam fakta persidangan terungkap bahwa para Terdakwa tidak ingin melakukan penganiayaan berat, namun hanya ingin memberi pelajaran kepada Novel Baswedan dengan melakukan penyiraman air keras. ${ }^{1}$

Jaksa mendakwa para Terdakwa dengan menggunakan konstruksi dakwaan primair Pasal 55 ayat 1 ke-1 jo. Pasal 355 ayat 1 KUHP tentang penganiayaan berat dengan rencana terlebih dahulu dengan ancaman maksimal 12 tahun penjara, subsidair Pasal 55 ayat 1 ke-1 jo. Pasal 353 ayat 1 dan 2 KUHP tentang penganiayaan dengan rencana lebih dahulu yang mengakibatkan luka berat dengan ancaman maksimal 7tahun penjara, lebih subsidair Pasal 55 ayat 1 ke-1 jo. Pasal 351 ayat 1 dan 2 KUHP tentang penganiayaan yang menyebabkan luka berat dengan ancaman maksimal 5 tahun penjara.

Jaksa berpendirian bahwa dalam kasus ini dakwaan primair tidak terbukti sehingga para Terdakwa harus dibebaskan dari dakwaan tersebut dan selanjutnya jaksa membuktikan dakwaan subsidair. Terkait dakwaan jaksa yang dinilai terlalu ringan apabila dibandingkan dengan ancaman maksimal dalam dakwaan subsidair, jaksa menyatakan bahwa alasan yang meringankan tuntutan adalah para Terdakwa mengakui terus terang perbuatannya dalam persidangan dan telah meminta maaf kepada ke-

1 Muhammad Irham dan Dwiki Marta, Novel Baswedan: Fakta-fakta dalam kasus 1.192 hari, penantian 'tanpa sentuh aktor intelektual', BBC Indonesia, 16 Juli 2020, diakses tanggal 5 Oktober 2020 luarga korban dan institusi Polri serta menyatakan menyesali perbuatan mereka.

Tulisan singkat ini hanya akan fokus pada uraian mengenai unsur "sengaja" dalam hukum pidana sebagai salah satu isu yang mengundang begitu banyak perdebatan dalam kasus ini.

Tindak Pidana adalah merupakan singkatan dari tindakan atau petindak. Artinya ada orang yang melakuan suatu tindakan sedangkan orang yang melakukan itu dinamakan petindak. Suatu tindakan hanya dilakukan oleh siapa saja, tetapi dalam banyak hal sesuatu tindakan tertentu hanya mungkin dilakukan oleh seorang dari suatu golongan, jenis kelamin saja atau seorang dari suatu golongan yang bekerja pada negara/ pemerintah/ pegawai negeri/ militer, nakhoda dan sebagainya atau seseorang dari golongan dan sebagainya atau seseorang dari golongan. ${ }^{2}$

Tindak Pidana menurut Wirjono Prodjodkoro adalah suatu perbuatan yang pelakunya dapat dikenakan hukuman pidana. Pelaku ini dapat dikatakan merupakan "subyek" tindak pidana. ${ }^{3}$

Tindak Pidana Menurut Simons adalah kelakuan (handeling) yang diancam dengan pidana, yang bersifat melawan hukum yang berhubungan dengan kesalahan dan yang dilakukan oleh orang yang mampu bertanggung jawab. ${ }^{4}$

Dalam pandangan kitab undang undang hukum pidana, yang dapat menjadi subjek tindak pidana adalah seorang manusia sebagai oknum ini mudah terlihat pada perumusan-perumusan dari tindak pidana dalam Kitab Undang-Undang Hukum pidana, yang menampakkan daya berpikir sebagai syarat bagi subjek tindak pidana itu, juga melihat pada wujud hukuman pidana

${ }^{2}$ Andi Hamzah, Asas-Asas Hukum Pidana, PT Rineka Cipta, Cetakan Kedua Edisi Revisi, 1994, hlm. 87.

${ }^{3}$ C.S.T Kansil, dan Cristine S.T Kansil, 2004, Pokok-Pokok Hukum Pidana (Hukum Pidana Untuk Tiap Orang), PT Pradnya Paramitha, Jakarta, hlm. 3

4 Moeljatno, 2009, Asas-Asas Hukum Pidana, PT Rineka Cipta, Jakarta, hlm. 61. 
yang termuat dalam Pasal-Pasal kitab undang-undang hukum pidana, yaitu hukuman penjara kurungan dan denda. ${ }^{5}$

Pertanggungjawaban pidana adalah pertanggungjawaban orang terhadap tindak pidana yang dilakukannya. Terjadinya pertangunggjawaban pidana karena telah ada tindak pidana yang dilakukan oleh seseorang. Pertanggungjawaban pidana pada hakikatnya merupakan suatu mekanisme yang dibangun oleh hukum pidana untuk bereaksi terhadap pelanggaran atas "kesepakatan menolak" suatu perbuatan tertentu. ${ }^{6}$

Roeslan Saleh menyatakan "bahwa pertanggungjawaban pidana diartikan sebagai diteruskannya celaan yang objektif yang ada pada perbuatan pidana dan secara subjektif memenuhi syarat untuk dapat dipidana karena perbuatannya itu".

Maksud celaan objektif adalah bahwa perbuatan yang dilakukan oleh seseorang memang merupakan suatu perbuatan yang dilarang. Indikatornya adalah perbuatan tersebut melawan hukum baik dalam arti melawan hukum formil maupun melawan hukum materiil. Sedangkan maksud celaan subjektif menunjuk kepada orang yang melakukan perbuatan yang dilarang tadi. Sekalipun perbuatan yang dilarang telah dilakukan oleh seseorang, namun jika orang tersebut tidak dapat dicela karena pada dirinya tidak terdapat kesalahan, maka pertanggungjawaban pidana tidak mungkin ada. Khusus terkait celaan objektif dan celaan subjektif ini, Sudarto mengatakan bahwa dipidananya seseorang tidaklah cukup apabila orang itu telah melakukan perbuatan yang bertentangan dengan hukum atau bersifat melawan hukum (celaan objektif). Jadi

5 Wirjono Prodjodikoro, 2009, Asas-Asas Hukum Pidana Di Indonesia, Refika Aditama, Bandung, hlm. 59.

${ }^{6}$ Chairul Huda, 2006, Dari Tiada Pidana Tanpa Kesalahan Menuju Kepada Tiada Pertanggungjawaban Pidana Tanpa Kesalahan, Kencana, Cet.Kedua, Jakarta, hlm.70.

${ }^{7}$ Roeslan Saleh dalam Hanafi Amrani dan Mahrus Ali, 2015, Sistem Pertanggungjawaban pidana Perkembangan dan Penerapan,PT Rajawali Press, Jakarta, hlm. 21. meskipun perbuatan tersebut memenuhi rumusan delik dalam undang-undang dan tidak dibenarkan, namun hal tersebut belum memenuhi syarat penjatuhan pidana. Untuk pemidanaan masih perlu adanya syarat untuk penjatuhan pidana, yaitu orang yang melakukan perbuatan itu mempunyai kesalahan dan bersalah (celaan subjektif). Orang tersebut harus bertanggungjawab atas perbuatannya atau jika dilihat dari sudut perbuatannya, perbuatannya baru dapat dipertanggungjawabankan kepada orang tersebut. $^{8}$

Secara lebih rinci, Sudarto menyatakan bahwa agar seseorang memiliki aspek pertanggungjawaban pidana, dalam arti dipidananya pembuat, terdapatbeberapa syarat yang harus dipenuhi, yaitu: ${ }^{9}$

1. Adanya suatu tindak pidana yang dilakukan oleh pembuat;

2. Adanya unsur kesalahan berupa kesengajaan atau kealpaan;

3. Adanya pembuat yang mampu bertanggungjawab;

4. Tidak ada alasan pemaaf.

Kesalahan adalah dapat dicelanya pembuat tindak pidana karena dilihat dari segi masyarakat sebenarnya dapat berbuat lain jika tidak ingin melakukan perbuatan tersebut. ${ }^{10}$

Orang dapat dikatakan mempunyai kesalahan, jika pada waktu melakukan perbuatan pidana, dilihat dari segi masyarakat dapat dicela karenanya, yaitu kenapa melakukan perbuatan yang merugikan masyarakat padahal mampu untuk mengetahui makna perbuatan tersebut, dan karenanya dapat bahkan harus menghindari perbuatan demikian. ${ }^{11}$

Dengan pengertian ini, maka pengertian kesalahan secara psikologis yang menititik beratkan pada kesalahan batin-

\footnotetext{
${ }^{8}$ Hanafi Amrani dan Mahrus Ali, 2015, Sistem Pertanggungjawaban Pidana Perkembangan dan Penerapan, Rajawali Press, Jakarta, hlm.,22

${ }^{9}$ Ibid, hlm.,22

${ }^{10}$ Ibid, hlm., 157.

${ }^{11}$ Mahrus Ali, 2012, Dasar-Dasar Hukum Pidana, Sinar Grafika, Cetakan Kedua, Jakarta, hlm. 157.
} 
(psychis) yang tertentu dari si pembuat dan hubungannya antara keadaan bantin tersebut dengan perbuatannya sedemikian rupa, sehingga pembuat dapat dipertanggungjawabankan atas perbuatannya, ${ }^{12}$ tidak diikuti karena menimbulkan persoalan dalam praktik hukum yang dipicu oleh ketiadaan unsur "dengan sengaja" atau "karena kealpaan" dalam rumusan tindak pidana. Dalam KUHP yang berlaku saat ini, tindak pidana pelanggaran tidak memuat unsur " dengan sengaja" atau karena kealpaan". Oleh karena itu, praktik hukum sempat diliputi pertanyaan sekitar apakah tidak dirumuskannya unsur "dengan sengaja" atau karena "kealpaan" dalam pelanggaran, menyebabkan pembuatnya tetap dipidana, sekalipuntidak ada salah satu dari kedua bentuk kesalahan tersebut. Persoalan ini timbul dan menyebabkan adanya keragu-raguan atas kemampuan teori kesalahan psikologis untuk menjelaskan masalah kesalahan. $^{13}$

Tujuan hukum dapat dilihat pada konsep tiga ide unsur dasar hukum yang dikemukakan oleh Gustav Radbruch. Ajarannya adalah konsep tiga ide unsur dasar hukum. Ketiga konsep dasar tersebut dikemukakan pada era Perang Dunia II. Tujuan hukum yang dikemukakannya tersebut oleh berbagai pakar diidentikkan juga sebagai tujuan hukum. Adapun 3 (tiga) tujuan hukum tersebut adalah kepastian, keadilan, dan kemanfaatan. Bagi Gustav Radbruch, ketiga unsur tersebut merupakan tujuan hukum secara bersama-sama, yaitu : keadilan, keman faatan, dan kepastian hukum. Namun demikian timbul pertanyaan, apakah ini tidak menimbulkan masalah dalam kenyataan, dimana seringkali antara kepastian hukum terjadi benturan dengan keadilan, atau benturan antara kepastian hukum dengan kemanfaatan hukum. Sebagai contoh, dalam kasus-kasus hukum tertentu, kalau hakim menginginkan keputusannya adil (menurut persepsi keadilan yang dianut oleh hakim) bagi si pelanggar atau tergugat atau terdakwa, maka akibatnya sering merugikan

\footnotetext{
${ }^{12}$ Ibid, hlm., 158 .

${ }^{13}$ Chairul Huda, Op.Cit., hlm. 73.
}

kemanfaatan bagi masyarakat luas. Sebaliknya, jika masyarakat luas dipuaskan, maka perasaan keadilan bagi orang tertentu terpaksa dikorbankan. Oleh karena itu, Gustav Radbruch mengajarkan bahwa hukum harus menggunakan asas prioritas, dimana prioritas pertama selalu keadilan, barulah kemanfaatan, dan terakhir barulah kepastian. ${ }^{14}$

Kepastian hukum sebagai salah satu tujuan hukum dapat dikatakan sebagai bagian dari upaya mewujudkan keadilan. Bentuk nyata dari kepastian hukum adalah pelaksanaan atau penegakan hukum terhadap suatu tindakan tanpa memandang siapa yang melakukan. Dengan adanya kepastian hukum setiap orang dapat memperkirakan apa yang akan dialami jika melakukan tindakan hukum tertentu. Kepastian diperlukan untuk mewujudkan prinsip persamaan dihadapan hukum tanpa diskriminasi. ${ }^{15}$

Ketika terjadi pelanggaran hak yang dilakukan oleh seseorang maka akan menimbulkan konsekuensi bahwa hukum tersebut akan dicabut dari dirinya berdasarkan putusan pengadilan yang adil. Selama ini terdapat konsepsi yang salah dalam penegakan hak asasi manusia. Seolah dalam keadaan apapun dan dalam hal apapun hak tersebut tidak dapat terhapuskan. Padahal sebagaimana konsepsi hak telah dipaparkan oleh para filsuf Yunani menyatakan bahwa hak selalu diimbangi dengan kewajiban. Ketika ada seseorang yang melakukan tindak pidana orang tersebutharus mendapatkan sanksi yang sesuai. Sanki juga bertujuan untuk mengembalikan ketentraman yang sempat terganggu akibat dilakukannya perbuatan tersebut. Sehingga pidana perlu ditegakkan dengan sebaik mungkin. Sebenarnya apakah yang menjadi alasan adanya disparitas tersebut. Sebagian besar hasil

${ }^{14}$ Theo Hujbers, 2007, Filsafat Hukum Dalam Lintasan Sejarah, Cetakan ke-XIV, Kanisius, Yogyakarta, hlm. 246.

${ }^{15}$ Moh. Mahfud MD, "Penegakan Hukum dan Tata Kelola Pemerintahan Yang Baik", makalah pada acara Seminar Nasional dengan tajuk "Saatnya Hati Nurani Bicara" yang diselenggarakan oleh DPP Partai HANURA di Jakarta pada tanggal 08 Januari 2009, hlm. 3 
penelitian menunjukkan bahwa hal tersebut ditentukan oleh sikap bathin dan rasa keadilan yang dimiliki oleh hakim. Menurut Suteki, seringkali sebagian masyarakat memahami hukum hanya sekedar sebagai perangkat peraturan hukum positif yang tercerabut dari pemahaman dari aspek filosofi dan sosiologisnya, sehingga gambar hukum yang ditampilkan tidak utuh melainkan hanya sebuah fragmen atau skeleton, yakni pe raturan perundang-undangan saja. Hal tersebut mendorong munculnya anggapan bahwa apabila kita telah menyelenggarakan hukum sebagaimana tertulis yang berupa huruf-huruf mati seolah-olah pekerjaan pencarian keadilan itu telah selesai. Akibatnya muncul kasus yang mencerminkan kondisi bahwa keadilan substansial telah teralienasi dari hukum. Hukum tidak membumi, bahkan menciderai rasa keadilan dalam masyarakat.11Aspek keadilan adalah aspek terpenting dalam penegakan hukum. Hukum tanpa keadilan bukanlah hukum. Keadilan itu sesungguhnya merupakan esensi dari hukum, hukum adalah keadilan, dan keadilan adalah hukum ius quia iustum. Relevansi penggunaan teori keadilan ini terkait penelitian mengenai unsur kesengajaan atas pemidanaan kecelakaan lalu lintas yang mengakibatkan hilangnya nyawa seseorang adalah bahwa keadilan sangat diperlukan sebagai tujuan hukum.

\section{B. PERMASALAHAN}

Dari uraian dan penjelasan diatas maka penulis mengajukan beberapa permasalahan yang akan dibahas dan menjadi pertanyaan dalam penelitian ini :

1. Apakah yang dimaksud dengan kesalahan?

2. Apakah pengertian "sengaja dan tidak sengaja" dalam hukum pidana Indonesia?

\section{KERANGKA TEORI}

Secara yuridis formal ( dalam KUHP ) tidak ada satu pasal pun yang memberikan "batasan / pengertian" tentang apa yang dimaksud dengan "kesengajaan". Makna ten- tang "kesalahan" dijumpai dalam penjelasan Resmi KUHP Belanda (Memory Van Toelichting). Di dalam Penjelasan Resmi KUHP Belanda itu "kesengajaan" atau opzet diartikan sebagai "menghendaki" dan "mengetahui" (willen en wetens). ${ }^{16}$

Seseorang yang berbuat dengan sengaja itu, harus dikehendaki apa yang diperbuatan harus diketahui pula atas apa yang diperbuat. Tidak termasuk perbuatan dengan sengaja adalah suatu gerakan yang ditimbulkan oleh reflek, gerakan tangkisan yang tidak dikendalikan oleh kesadaran. Dalam pengertian ini disebutkan bahwa kesengajaan diartikan sebagai: "menghendaki dan mengetahui" (willens en wetens). Artinya, seseorang yang melakukan suatu tindakan dengan sengaja, harus menghendaki serta menginsafi tindakan tersebut dan/ atau akibatnya. Jadi dapatlah dikatakan, bahwa sengaja berarti menghendaki dan mengetahui apa yang dilakukan. Orang yang melakukan perbuatan dengan sengaja menghendaki perbuatan itudan disamping itu mengetahui atau menyadari tentang apa yang dilakukan itu dan akibat yang akan timbul dari padanya.

Berkaitan dengan masalah "kesengajaan" didalam wacana ilmu pengetahuan hukum pidana (doktrin) dikenal adanya dua teori tentang kesengajaan, yaitu :

a. Teori "Kehendak" (wilstheorie) Menurut teori iniu, seseoranmg dianggap "sengaja" melakukan suatu perbuatan (pidana) apabila orang itu "menghendaki" dilakukannya perbuatan itu. Dengan demikian seseorang dikatakan telah dengan "sengaja" melakukan suatu perbuatan (pidana) apabila dalam diri orang itu ada "kehendak" untuk mewujudkan unsur-unsur delik dalam rumusan undang-undang.

b. Teori "Pengetahuan/Membayangkan" (voorstelling-theorie).

Menurut teori ini, "sengaja" berarti "membayangkan" akan timbulnya aki-

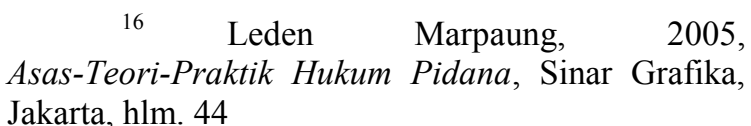


bat perbuatannya. Dalam pandangan teori ini orang tidak bisa "menghendaki" akibat (suatu perbuatan), tetapi hanya bisa "membayangkan" (akibat yang akan terjadi). Terhadap perbuatan yang dilakukan si pelaku kedua teori itu tak ada menunjukkan perbedaan, kedua-duanya mengakui bahwa dalam kesengajaanharus ada kehendak untuk berbuat. Dalam praktek penggunaannya, kedua teori adalah sama.

Perbedaannya adalah hanya dalam peristilahannya saja. Pengertian "kesengajaan" dalam hukum pidana dikenal 2 (dua) teori, yaitu:

1. Teori Kehendak (Wilstheorie)

2. Teori Membayangkan (Voorstellingsth eorie); Teori Kehendak (Wilstheorie) dikemukakan oleh Von Hippel dalam bukunya Die Grenze Vorsatz und Fahrlassigkeit tahun 1903, yang menyatakan kesengajaan adalah kehendak mem buat suatu tindakan dan kehendak menimbulkan suatu akibat dari tindakan itu. Akibat dikehendaki apabila akibat itu yang menjadi maksud dari tindakan tersebut; Teori membayangkan (Voorstellingstheorie) dikemukakan oleh Fran $\mathrm{k}$ dalam bukunya Festschrift Gieszen tahun 1907 yang menyatakan bahwa manusia tidak mungkin dapat menghen daki suatu akibat; manusia hanya dapat mengingini, mengharapkan dan memba yangkan (voorstellen) kemungkinan adanya suatu akibat;

Teori tentang kehendak terbagi men jadi 2 (dua) ajaran, yaitu:

1. Determinisme, berpendapat bahwa manusia tidak mempunyai kehendak bebas. Manusia melakukan suatu perbuatan didorong oleh beberapa hal, baik yang berasal dari dalam dirinya maupun dari luar dirinya;

2. Indeterminisme, aliran ini muncul sebagai reaksi dari aliran determinasi, yang menyatakan bahwa walaupun untuk melakukan sesuatuperbuatan dipengaruhi oleh bakat dan milieu, manusia dapat menentukan kehendaknyasecara bebas;

Aliran Determinisme tidak dapat diterapkan dalam hukum pidana karena akan menimbulkan kesulitan dalam hal pertanggungjawaban. Sehingga muncul Determinisme Moldern yang menyatakan bahwa Manusia adalah anggota masyarakat, dan sebagai anggota masyarakat apabila melanggar ketertiban umum, maka ia bertanggungjawab atas perbuatannya. ${ }^{17}$

Macam-Macam Kesengajaan.Dalam doktrin ilmu hukum pidana, kesenggajaan (dolus) mengenal berbagai macam keseng gajaan, antara lain: ${ }^{18}$

1. Dolus Determinatus; Adalah keseng ajaan tertentu, yaitu kesengajaan ya ng ditujukan kepada objek tertentu.

2. Dolus Indeterminatus; Adalah ke sengajaan tidak tertentu, yaitu kese ngajaan yang tidak ditujukan kepada objek tertentu, tetapi pada sambarang objek.

3. Dolus Alternativus; Adalah kesengajaan alternatif, yaitu kesengajaan yang ditujukan kepada objek yang satu atau kepada objek yang lainnya. Jadi memilih di antara dua objek.

4. Dolus Generalis; Adalah kesengajaan umum, yaitu kesengajaan yang ditujukan kepada umum. Contoh: melempar bom ke tengah pasar yang sedang ramai.

5. Weberse Dolus Generalis; Adalah kesengajaan yang ditujukan kepada objek tertentu, tetapi untuk mencapai tujuan itu dilakukan lebih banyak perbuatan.

6. Dolus Indirektus; Adalah kesengajaan terhadap suatu perbuatan yang menimbulkan suatu akibat yang

17 P.A.F.Lamintang, 2007, Dasar-Dasar Hukum Pidana Indonesia, Sinar Baru, Bandung, hlm. 311

18 Teguh Prasetyo dan Abdul Hakim Barkatullah, 2005, Politik Hukum Pidana Kajian Kebijakan Kriminalisasai dan Deskriminalisasi, Pustaka Pelajar, Yogyakarta, hlm. 31 
sebenarnya bukan merupakan kehendak atau tujuan si pelaku.

7. Dolus Premiditatus, Adalah kesengajaan yang direncanakan terlebih dahulu (met voorbedachte raad). Misalnya: Pasal 340 KUHP tentang pembunuhan berencana (moord).

8. Dolus Repentinus/Dolus Impetus; Yaitu kesengajaan yang timbul dengan serta merta. Misalnya: Pasal 338 KUHP tentang pembunuhan biasa (doodslag).

9. Dolus Formel; Adalah kesengajaan yang ditujukan kepada suatu per buatan. Contohnya: Pasal 362 KUHP tentang pencurian.

10. Dolus Materiil; Adalah kesengajaan yang ditujukan kepada suatu akibat atau suatu keadaan. Contohnya: $\mathrm{Pa}$ sal 338 KUHP tentang pembunuhan.

- Kekeliruan Pada Kesengajaan

1. Error Juris/Recht dwaling (kekeliruan tentang hukum); Adalah melakukan suatu perbuatan yang dilarang oleh undang-undang, dengan perkiraan bahwa perbuatan itu tidak dilarang oleh undang-undang.

2. Error Facti/Feitelijke dwaling (keke liruan tentang unsur tindak pidana); Adalah kekeliruan tentang tidak ada kesengajaan yang ditujukan pada salah satu unsur tindak pidana, sehingga si pelaku tidak dapat dipidana.

3. Error in Persona (kekeliruan tentang orang); Adalah kekeliruan tentang orang yang menjadi tujuan dari tindak pidana.

4. Error in Objecto (kekeliruan tentang objek); Adalah kekeliruan tentang objek yang menjadi tujuan dari tindak pidana.

5. Aberratio Ofdwalings geval (penyimpangan sasaran); Adalah penyimpangan sasaran dari yang menjadi tujuan tindak pidana.

\section{PEMBAHASAN}

1. Yang dimaksud dengan kesalahan?

A. Tiada Pidana Tanpa Kesalahan, istilah tiada pidana tanpa kesalahan:

1. Geen straf zonder schuld (Belanda)

2. Ohne schuld keine strafe (Jerman)

3. Actus non facit reum, nisi mens sit rea (Latin)

4. An act does not make a person guilty, unless the mind is guilty (Inggris)

Menurut R. Achmad S. Somadipradja $\mathrm{SH}$, asas Geen straf zonder schuld itu kini bukan merupakan asas di luar perundangundangan, karena Pasal 6 ayat 2 Undangundang No. 48 Tahun 2009 tentang Kekuasaan Kehakiman menentukan:"Tidak seorang pun dapat dijatuhi pidana, kecuali apabila pengadilan karena alat pembuktian yang sah menurut undang-undang, mendapat keyakinan bahwa seseorang yang dianggap dapat bertanggung jawab, telah bersalah atas perbuatan yang didakwakan atas dirinya".

Asas tiada pidana tanpa kesalahan juga dapat dihubungkan dengan:

1. Fungsi yang negatif dari sifat melawan hukum yang materiil (Arrest dokter hewan 1933); Mengecualikan perbuatan yang sesuai dengan rumusan undang-undang pidana, tetapi tidak merupakan tindak pidana sehingga perbuatan itu tidak dapat dipidana.

2. Arrest Hoge Raad (MA Belanda) tanggal 14 Februari 1916 yang disebut Melkboer Arrest (Keputusan Susu dan Air)

B. Pengertian Kesalahan (Schuld) Pengertian Kesalahan secara yuridis terdiri dari:

1. Kesalahan dalam arti etis sosial (schuld in social ethische),yang berarti hubungan jiwa dari seseorang yang melakukan perbuatan dengan perbuatan yang dilakukannya atau dengan akibat dari perbuatannya itu, 
sedemikian rupa sehingga perbuatan atau akibat dari perbuatannya itu dapat dipertanggungjawabkan kepadanya. Jenis kesalahan ini disebut dengan kesalahan dalam arti luas (schuld inruimezin). Adapula kesalahan dalam arti sempit (schuld in engezin), adalah salah satu bentuk dari kesalahan yaitu kealpaan.

2. Kesalahan dalam arti hukum pidana (schuld instrafrechtelijke), yang berarti bentuk-bentuk kesalahan, yaitu kesengajaan (dolus) dan kealpaan (culpa).

Pengertian kesalahan menurut para ahli hukum adalah sebagai berikut:

a) Simons

Bahwa sebagai dasar dari pertanggungjawaban adalah kesalahan yang terdapat pada jiwa pelaku dalam hubungannya (kesalahan itu) dengan kelakuannya yang dapat dipidana dan berdasarkan kejiwaannya itu pelaku dapat dicela karena kelakuannya itu.Untuk adanya kesalahan pada pelaku, harus dicapai dan ditentukan terlebih dahulu beberapa hal yang menyangkut pelaku yaitu:

1. Kemampuan bertanggung jawab (to erekenings vatbaarheid)

2. Hubungan kejiwaan antara pelaku dan akibat yang ditimbulkan

3. Dolus atau culpa

b) Utrecht

Bahwa pertanggungjawaban pidana atau kesalahan menurut hukum pidana (schuld in ruime zin) terdiri atas 3 aspek:

1. Toerekenings vatbaarheid dari pembuat

2. Suatu sikap psikis pembuat yang berhubungan dengan kelakuannya, yakni: (a) Kelakuan disengaja (aspek sengaja), dan

(b) Kelakuan yang berupa suatu sikap kurang hati-hati (kealpaan) atau schuld in enge zin.
3. Tidak ada alasan-alasan yang menghapuskan pertanggungjawaban pidana pembuat

c) Roeslan Saleh dan Moeljatno

Unsur-unsur kesalahan adalah sebagai berikut:

1. Mampu bertanggungjawab

2. Mempunyai kesengajaan atau kealpaan

3. Tidak adanya alasan pemaaf

Ketiga unsur kesalahan tersebut harus dihubungkan dengan perbuatan pidana yang telah dilakukan. Untuk adanya kesalahan yang mengakibatkan dipidananya terdakwa, maka terdakwa harus:

1. Melakukan perbuatan pida- na

2. Mampu bertanggungjawab

3. Dengan kesengajaan atau kea lpaan

4. Tidak adanya alasan pemaaf.

2. Pengertian "Sengaja dan Tidak Sengaja" dalam hukum pidana Indo nesia?

Kesengajaan dalam rumusan ting kat pidana dapat dibagi menjadi tiga bagian: ${ }^{19}$ a.Istilah kesenga jaan dalam KUHPTindak pidana yang dirumuskan dalam KUHP me muat unsur kesengajaan (objek). Berbagai istilah ksengajaan yang digunakan oleh pembentuk unda ng-undang dalam KUHP adalah :

1) Dengan sengaja Istilah ini antara lain dapat dilihat dalam Pasal 372 KUHP dan Pasal 338 KUHP2.Yang diKetahuinya Istilah ini dapat dilihat da lam beberapa Pasal misalnya Pasal 286 KUHP dan 480 KUHP3.Dengan

MaksudIstilah ini antara lain 362 KUHP dan Pasal 368 (satu KUHP)b. Penempatan ke sengajaan dalam rumusan tindak pidana.Apabila dalam ru-

${ }^{19} \mathrm{~W}$ Prodjodikoro, 2005, Asas-Asas Hukum Pidana Di Indonesia, P.T.Eresco, Jakarta, hlm. 113. 
musan tindak pidana digunakan istilah dengan sengaja untuk menunjukkan adanya unsur kesengajaan maka unsur ya ng dirumuskan dibelakang unsur kesengajaan tersebut harus dianggap diliputi oleh keseng ajaan dengan kata lain dapat di katakan bahwa apabila dalam rumusan tindak pidana digunakan istilah dengan sengaja maka unsur-unsur tindak pidana yang terletak dibelakang unsur itu dijiwai oleh unsur kesengajaan.

2) Apabila unsur kesengajaan dirumuskan ditengah-tengah unsur yang lain dalam rumusan tindak pidana maka konsekuensinya adalah bahwa unsur yang letaknya dibelakanhg unsur kesengajaanharus dianggap dijiwai oleh unsur kesengajaan.

3) Dalam hal kesengajaan itu tidak dirumuskan secara tegas dalam rumusan tindak pidana. Apabila dicermati rumusan tin dak pidana dalam KUHP akan juga terlihat bahwa dalam beberapa Pasal KUHP sama sekali tidak dirumuskan adanya unsur kesengajaan. Apabila da lam rumusan tindak pidana tidak dirumuskan adanya unsur kesengajaan secara tegas maka untuk menentukan apakah tindak pidana itu merupakantindak pidana yang berunsur kesengajaan atau tidak harus dilakukan dengan interpretasi/penafsiran.

\section{E. PENUTUP}

Berdasarkan uraian diatas maka dapatlah ditarik suatu kesimpulan bahwa :

1. Yang dimaksud dengan kesalahan adalah Kesalahan adalah dasar untuk pertanggungjawaban. Kesalahan merupakan keadaan jiwa dari si pembuat dan hubungan batin antara si pembuat dan perbuatannya. Mengenai keadaan jiwa dari seseorang yang melakukan perbuatan, lazim disebut sebagai kemampuan bertanggung jawab, sedangkan hubungan batin antara si pembuat dan perbuatannya itu merupakan kesengajaan, kealpaan, serta alasan pemaaf.Dengan demikian, untuk menentukan adanya kesalahan, dalam pidana subjek hukum harus memenuhi beberapa unsur, antara lain:

a) Adanya kemampuan bertanggung jawab pada si pelaku,

b) Perbuatannya tersebut berupa kesengajaan (dolus) atau kealpaan (cul$p a)$;

c) Tidak adanya alasan penghapus kesalahan atau tidak adanya alasan pemaaf.

2. Pengertian "Sengaja dan Tidak Sengaja" dalam hukum pidana Indonesia adalah Kesengajaan itu adalah "menghendaki" dan "mengetahui" (willens en wetens). Maksudnya adalah seseorang yang melakukan suatu perbuatan dengan sengaja itu, haruslah menghendaki (willens) apa yang ia perbuat dan harus mengetahui pula (wetens) apa yang ia perbuat tersebut beserta akibatnya.

\section{DAFTAR PUSTAKA}

Andi Hamzah, Asas-Asas Hukum Pidana, PT Rineka Cipta, Cetakan Kedua Edisi Revisi, 1994.

C.S.T Kansil, dan Cristine S.T Kansil, 2004, Pokok-Pokok Hukum Pidana (Hukum Pidana Untuk Tiap Orang), PT Pradnya Paramitha, Jakarta. 
Chairul Huda, 2006, Dari Tiada Pidana Tanpa Kesalahan Menuju Kepada Tiada Pertanggungjawaban Pidana Tanpa Kesalahan, Kencana, Cet.Kedua, Jakarta.

Hanafi Amrani dan Mahrus Ali, 2015, Sistem Pertanggungjawaban Pidana Perkembangan dan Penerapan, Rajawali Press, Jakarta.

Leden Marpaung, 2005, Asas-Teori-Praktik Hukum Pidana, Sinar Grafika, Jakarta.

Mahrus Ali, 2012, Dasar-Dasar Hukum Pidana, Sinar Grafika, Cetakan Kedua, Jakarta.

Moeljatno, 2009, Asas-Asas Hukum Pidana, PT Rineka Cipta, Jakarta.

Moh. Mahfud MD, "Penegakan Hukum dan Tata Kelola Pemerintahan Yang Baik", makalah pada acara Seminar Nasional dengan tajuk "Saatnya Hati Nurani Bicara" yang diselenggarakan oleh DPP Partai HANURA di Jakarta pada tanggal 08 Januari 2009.

Muhammad Irham dan Dwiki Marta, Novel Baswedan: Fakta-fakta dalam kasus 1.192 hari, penantian 'tanpa sentuh aktor intelektual', BBC Indonesia, 16 Juli 2020, diakses tanggal 5 Oktober 2020

P.A.F.Lamintang, 2007, Dasar-Dasar Hukum Pidana Indonesia, Sinar Baru, Bandung.

Roeslan Saleh dalam Hanafi Amrani dan Mahrus Ali, 2015, Sistem Pertanggungjawaban pidana Perkembangan dan Penerapan,PT Rajawali Press, Jakarta.

Teguh Prasetyo dan Abdul Hakim Barkatullah, 2005, Politik Hukum Pidana Kajian Kebijakan Kriminalisasai dan Deskriminalisasi, Pustaka Pelajar, Yogyakarta.

Theo Hujbers, 2007, Filsafat Hukum Dalam Lintasan Sejarah, Cetakan ke-XIV, Kanisius, Yogyakarta.

W Prodjodikoro, 2005, Asas-Asas Hukum Pidana Di Indonesia, P.T.Eresco, Jakarta.

Wirjono Prodjodikoro, 2009, Asas-Asas Hukum Pidana Di Indonesia, Refika Aditama, Bandung. 
